\title{
Management of Fruit Rot of Brinjal Caused by Phomopsis vexans
}

\author{
Y.N. Priya Reddy*, S.S. Jakhar and O.S. Dahiya \\ Department of Seed Science and Technology, \\ College of Agriculture, CCS HAU, Hisar-125004, Haryana, India \\ *Corresponding author
}

\section{A B S T R A C T}

\section{Keywords}

Brinjal, Fruit rot, Phomopsis vexans, Carbendazim, Trichoderma

Article Info

Accepted:

20 May 2018

Available Online:

10 June 2018
A few reviews on control of Phomopsis vexans of brinjal are reported in the literature. This review is added with recent research work, pertaining to practical applications besides the academic importance. The review includes the diseases caused by Phomopsis vexans, yield losses and methods of control. Although control methods like mechanical, chemical, biological and integrated are discussed here, it would be apt to recommend and practice the biological methods of control in the changing climate scenario, drudgery in mechanical methods and to maintain the safe environment. The plant extracts like neem oil, neem cake, plant leaf extracts, plant derived compounds like Nimbidine or bio-fungicides like species of Trichoderma would be the better options for control of Phomopsis vexans of brinjal and thus to achieve potential fruit yield.

\section{Introduction}

Brinjal (Solanum melongena L.) belongs to family Solanaceae. It is the most important vegetable in India (Sekara et al., 2007) and described as "king of vegetables" due to its wide usage in Indian foods (Choudhary and Gaur, 2009; Singh et al., 2014). Area, production and productivity of brinjal have increased over the years, although increment in productivity remained relatively less over the years (Anon, 2015 and NHB, 2017). Globally, India stands $2^{\text {nd }}$ in brinjal production; and in India, brinjal constitutes 8.1 per cent of vegetable production (Anon, 2012;
Anon, 2013; Anon, 2015). Presently, brinjal ranks $4^{\text {th }}$ important vegetable crop in India after potato, onion and tomato. Brinjal is cultivated in an area of 0.72 million ha with a production of 12.32 million tones and productivity of $16.95 \mathrm{t} \mathrm{ha}^{-1}$ during the year 2016-17 (NHB, 2017). Although, the productivity of brinjal in India has increased, it is far less than the productivity in a few other countries viz., China, Japan, Turkey, Egypt and Italy (Anon, 2012). Such lower production could be attributed to several environmental, edaphic and plant factors. Among the various production constraints in brinjal, diseases are the prominent factor in 
determining the fruit production (Ali et al., 2012; Bhatti et al., 2013). The predominant diseases of brinjal those reduce the fruit yield are (i) Phomopsis fruit rot (Das and Sharma, 2012; Islam and Meah, 2011; Ghosh, 2017), (ii) Phomopsis blight, (iii) damping off, (iv) little leaf and (v) viral leaf yellowing.

The little leaf of whole plant under severe infection or braches at the initial stages appears as bushy leaves arising from a single node due to highly reduced leaf size with reduced internode length. The little leaf incidence was relatively low, varying from 2.4 to 12.5 per cent among 25 varieties (Bhushan and Samnotra, 2017). However, Rathnamma (2014) reported a higher little leaf incidence from 20.1 to 34.6 per cent. Such incidence lead to an estimated loss of fruit yield ranging from 67.2 to 100.0 per cent especially when crop infected at younger stages due to reduced fruit number per plant (Chakrabarti and Chowdhury, 1979; Rangaswamy and Mahadevan, 2002; Kevin, 2006). Another disease, viral leaf yellowing found to cause yield loss from 9.51 to 27.0 per cent (Singh and Singh, 1975).

The damping off, Phomopsis blight and fruit rot are caused by the Phomopsis vexans (Udayanga et al., 2011; Jayaramaiah et al., 2013) and was first reported from Gujarat in 1914 and then from almost all the states wherever brinjal is grown (Rangaswamy and Mahadevan, 2002). Phomopsis vexans primarily infect the seed coat (2\%), cotyledons (4\%) and embryo axis (4\%) and attacks all the above ground plant parts (Thippeswamy et al., 2005).

The damping off occur both in nursery and seedling stage will show symptoms of soft, water soaked and rotting of stem / root portion of the tissue at collar region of seedling. Such seedling rot caused by Phomopsis vexans (rot of seedlings) is due to lack of translocation of food material from leaf to roots, loss of mechanical support and consequent plant death (Singh, 1992; Ashrafuzzaman, 2006). Such pre and post emergence damping off can be effectively controlled by seed treatment with carbendazim (Mohanty et al., 1994; Kaushal and Sugha, 1995) and combination of carbendazim + thiram (Kaushal and Sugha, 1995). Another study showed seedling rot (7\%) and fruit rot $(21 \%)$ caused by $P$. vexans leading to yield losses of 15-50 per cent (Das, 1998).

The Phomopsis blight symptoms are grey to brown circular spots on the leaves or stem, which eventually becomes yellow and dry and at severe conditions as cankers on petiole and stem. While Phomopsis fruit rot is the water soaked lesions on fruit. The Phomopsis blight will be noticed from 25 to 28 days after inoculation and fruit rot incidence from 45 to 55 days after inoculation of $P$. vexans, these incidences vary with geographic location, soil type and weather (Meah et al., 2002; Ali et al., 2017). In Karnataka, Mahadevakumar and Janardhan (2015) reported a wide range of Phomopsis blight from 7.7 to 30.5 per cent with fruit rot ranging from 21.0 to 64.6 per cent. Jayaramaiah et al., (2013) reported that Phomopsis vexans cause leaf blight to the extent of 5 to 23 per cent and fruit rot to the extent of 30 to 60 per cent. Recently Mahadevakumar et al., (2017) reported leaf blight incidence (8 to $25 \%$ ) and fruit rot incidence (15 to $62 \%$ ) caused by $P$. vexans. In another recent study, the Phomopsis blight incidence ranged from 8.81 to 23.85 per cent among 25 genotypes (Bhoshan and Samnotra, 2017). Phomopsis fruit rot may go as high as 12.5 to 85.0 per cent depending on variety (Pandey et al., 2002). The fruit rot disease incidence varies with different isolates or locations. For instance, fruit rot incidence varied from 20.0 to 55.8 per cent depending on the isolate of $P$. vexans in brinjal (Akhtar and Chaube, 2006). Such a high degree of 
disease incidence would lead to huge losses in fruit yield.

\section{Yield losses due to Phomopsis vexans}

Under normal weather conditions, fruit rot caused by Phomopsis vexans lead 12 to 25 per cent yield loss due to flower drop and fruit rot (Kannan et al., 1998). It reduces yield and marketable value of the crop from 20 to 50 per cent (Panwar et al., 1970; Jain and Bhatnagar, 1980; Kaur et al 1985; Das, 1998; Khan, 1999; Thippeswamy et al., 2005; Akhtar et al., 2008; Beura et al., 2008; Pandey, 2010; Jayaramaiah et al., 2013). Such a huge loss in fruit yield due to Phomopsis fruit rot was attributed to decreased fruit number $(34.8 \%)$ and fruit weight $(17.0 \%)$ as reported by Kidasha (2010) and due to poor seed germination and plant stand due to Phomopsis infection (Thippeswamy et al., 2005). Loss in fruit yield was as high as $70 \%$ due to Phomopsis vexans (Chistina, 2002). Therefore, management of Phomopsis vexans is very important to increase the brinjal productivity and production.

\section{Management of Phomopsis vexans}

Seeds are the main source of infection of $P$. vexans and serves as substrate for survival of fungus until next season (Vishunavat and Kumar, 1993; Pan and Acharya, 1995) or even up to 14 months (Kalda et al., 1977). The soil borne spores of $P$. vexans generally dispersed by rain splashes, and through rotten parts and insects (Singh, 1992; Mahadevakumar and Janardhan, 2016). The Phomopsis vexans causes poor seed germination, damping-off and lesions on leaf, stem and fruit, both in the field and after harvest (Chaudhury and Kalda, 1968; Das, 1998) and the severity of disease caused by $P$. vexans is increasing over the years. Phomopsis blight occurs at seedling stage in nursery as well as in transplanted crop. The symptoms are small circular spots develops on leaves, turn grey later with light coloured centre. On stem, the symptoms include brown or dark sunken lesions slightly above the soil surface and may result in cankers and eventual seedlings death. On fruit surface a pale, sunken, oval areas are observed and these symptoms enlarge and become depressed (Ronald, 2009). Hence, there is a need to screen and identify genotypes for disease resistance in crop improvement and or to adopt appropriate control measures for immediate purposes (Mahadevakumar and Janardhan, 2016). The common methods are cultural, chemical, biological and integrated control.

\section{Mechanical / cultural methods}

The Phomopsis vexans is soil as well as seed borne, survives on seed surface and inside the seed, and disseminated through rain splash (Khalil et al., 2013; Mahadevakumar and Janardhan, 2016). Several mechanical / cultural methods are reported for control the Phomopsis vexans as detailed below.

(i) Use of healthy seed found to show higher seed germination of 84.8 per cent with lower damping off incidence $(1.75 \%)$ and seedling blight $(3.5 \%)$ as against diseased seed (28.0 $\%$ seed germination, $30.25 \%$ damping off and $26.25 \%$ seedling blight). Therefore, it is appropriate to collect the seeds from healthy plants (disease-free) and use for sowing (Islam and Meah, 2011).

(ii) Use of resistant varieties is one of the most effective methods of disease control as the chemical control will not be effective in all the weather conditions. In India, sources of resistance have been identified (Datar and Ashtaputre, 1988). Although no resistant genotypes are available for Phomopsis fruit rot among 36 genotypes tested (Pandey et al., 2002), a few relatively resistant (with least fruit rot incidence) varieties of brinjal viz., 
Pant Samrat, Florida beauty, Florida market, PB-30, BC-1, JC-2, KS-352 have been reported against Phomopsis blight. However, the wild species resistant to Phomopsis blight viz., S. nigrum, S. xanthocarpum, S. gilo, $S$. testiculam, $S$. khasianum and $S$. torvum can be utilised in breeding programme for development of resistant varieties to Phomopsis blight and fruit rot (Kalda et al., 1976; Agrawal et al., 2000). The Phomopsis blight caused by Phomopsis vexans is highly heritable (Bhardwaj et al., 2014). In this direction, Khalil et al., (2013) have proved the possibility of achieving tolerance by crossing between tolerant and susceptible brinjal genotypes and selection in $\mathrm{F}_{4}$ generation. Recently, Karmakar and Singh (2017) have developed moderately resistant lines for fruit rot resistance from interspecific crosses between susceptible cultivated variety ( $S$. melongena; susceptible) and wild species ( $S$. gilo; resistant). Disease free varieties namely, Pusa bhairabi and Pusa cluster were recommended for cultivation to avoid the Phomopsis blight and fruit rot (Singh et al., 2014). Further, hybrids observed to show less incidence of Phomopsis blight compared to farmer-collected seeds (Mahadevakumar et al., 2017).

(iii) Hot water treatment has been one of the physical methods recommended to reduce the disease infection without affecting the seed viability. In this regard hot water treatment of seeds at $50{ }^{0} \mathrm{C}$ for $30 \mathrm{~min}$ or $56{ }^{\circ} \mathrm{C}$ for $15 \mathrm{~min}$ can be used to control the disease incidence, as the fungus is sensitive to high temperature (Islam and Meah, 2011; Singh et al., 2014). The disease infection and spread are highly influenced by weather conditions. The incidence of Phomopsis blight was high during humid conditions (Mahadevakumar et al., 2017). The temperature of $25{ }^{\circ} \mathrm{C}$ and $\mathrm{pH}$ 5.5 were optimum for the best growth of $P$. vexans on PDA culture media in 7 days at $12 / 12 \mathrm{D} / \mathrm{N}$ and; the spore formation was decreased by $30{ }^{0} \mathrm{C}$ and reached to zero by 35 ${ }^{0} \mathrm{C}$ (Islam et al., 2009). This could explain the seed treatment with hot water treatment at 50 ${ }^{0} \mathrm{C}$ for $30 \mathrm{~min}$. The light, $12 / 12 \mathrm{D} / \mathrm{N}$ was the best for sporulation and growth of $P$. vexans and continuous light or continuous dark and U.V. light reduces the growth and sporulation of $P$. vexans (Islam et al., 2009), suggesting that the light is essential for growth and sporulation of $P$. vexans. Further, $\mathrm{pH}$ of 4.0 to 7.0 is an optimum but maximum growth and sporulation will occur at $5.5 \mathrm{pH}$ (Islam et al., 2009).

(iv) The survived fungus in soil, seed and debris of brinjal will be carry forwarded to the next generation or next season, hence burning of crop debris and burying them by deep ploughing would help to reduce disease incidence (Singh, 1987).

(v) Use of lower dose of nitrogen with higher rates of phosphorus and potassium are also useful in control of Phomopsis vexans to certain extent (Sugha and Kumar, 2003).

(vi) Practice of crop rotation is another mechanical method. Although brinjal is the significant host for Phomopsis vexans, the fungus is capable of growing well on number of alternate host plants such as cauliflower, carrot, beet-root and solanaceae weeds (Anon, 2017). Therefore, choice of crop for crop rotation to reduce the inoculum should be taken care.

\section{Chemical control}

Compared to the mechanical methods which are drudgery, chemical control measures have been widely adopted with time owing to their high efficiency in controlling the diseases in addition to ease of application either as seed treatment or foliar application. Most common fungicides used for seed treatment and foliar spray are, Carbendazim (bavistin), Dithane M- 
45 (Mancozeb), Dithane Z-78 (Mancozeb) and Copper oxychloride (blitox-50) (Singh and Chakrabarti, 1982; Mohanty et al., 1994; Kaushal and Sugha, 1995; Pandey, 2010a; Singh et al., 2012; Vinodkumar, 2012; Das et al., 2014; Singh et al., 2014; Rohini et al., 2015; Chaukhe et al., 2017; Jakatimath et al., 2017; Priya Reddy et al., 2017). Confirming the results of other workers, Beura et al., (2008) and Phansawan et al., (2015) found that carbendazim provided the best control of Phomopsis vexans and maximising the yield. Chaukhe et al., (2017) showed that foliar spray of carbendazim $(0.1 \%)$ at the onset of disease incidence and twice thereafter at 15 day interval gave highest fruit yield by controlling the Phomopsis rot with a meagre fruit rot incidence of only 10.35 per cent as against 33.66 per cent in control. Further, it was confirmed through laboratory study wherein, carbendazim completely inhibited the mycelia growth of Phomopsis vexans (Mohanty et al., 1994; Priya Reddy et al., 2017) as the sensitivity of Phomopsis spore germination to the fungicide was high (Sugha and Kumar, 2003).

Several chemicals have been tested and recommended for seed treatment with bavistin $\left(1 \mathrm{~g} \mathrm{~kg}^{-1}\right.$ seed) or seedling treatment $(0.05 \%$ solution) for 30 minutes or foliar spray $(0.05 \%)$ at 10 to 15 days interval for control of $P$. vexans effectively (Pandey, 2010a). Seed treatment with thiram $\left(2 \mathrm{~g} \mathrm{~kg}^{-1}\right.$ seed) protects the seedling in the nursery stage.

Spraying with Dithane Z-78 (0.2\%) or Bordeaux mixture (1\%) effectively controlled the Phomopsis blight caused by $P$. vexans in the field (Vinodkumar, 2012). The chemicals like, bavistin $(0.1 \%)$, vitavax $(0.1 \%)$, blitox -50 $(0.2 \%)$, and ridomil $(0.15 \%)$ proved to be most effective in inhibiting the growth of Phomopsis pathogen in-vitro and in controlling the disease under field conditions (Singh et al., 2012). Singh et al., (2014) reported that Phomopsis blight and fruit rot caused by $P$. vexans can be effectively controlled by spraying zineb (Dithane Z-78) or mancozeb (Dithane M-45) at $2.5 \mathrm{~g} \mathrm{~L}^{-1}$ of water. The fruit rot incidence was reduced from 67.6 per cent in control to 14 per cent in carbendazim and other fungicides viz., propiconazole $(0.15 \%)$, copper oxychloride $(0.3 \%)$ and $0.15 \%$ metalaxyl + mancozeb sprayed twice at 15 day interval (Ali et al., 2017).

Fungicides such as carbendazim, mancozeb and captan have reduced seed borne fungi and controlled the fruit rot caused by Phomopsis vexans (Thippeswamy et al., 2005). Das et al., (2014) reported that the carbendazim $(0.1 \%)$ inhibited mycelia growth of Phomopsis vexans by 100 per cent and carbendazim was more effective as compared to the captan, macnozeb and ridomil in inhibition the mycelia growth of Phomopsis vexans. However, there are emerging evidences to show that the fungus is becoming resistant against these fungicides (Islam and Sitansu, 1989; Thippeswamy et al., 2006).

Other problem associated with chemical fungicides is their accumulation in different plant parts including the fruit. Further, the chemical control in long run or indiscriminate use lead to residue accumulation in soil, risk of ground water pollution, death of nontargeted flora and fauna, fungicide resistance, death of beneficial soil micro-flora and consumer health (Campbell, 1989; Rajavel, 2000; Avinash and Hosmani, 2012). Therefore, alternatives are indeed essential in the climate change scenario although fungicides combined with cultural control methods are most effective (Howard and David, 2007). To avoid the adverse effects of chemicals, alternative biological agents are emerging as alternative strategies, being widely considered for their low cost, sustainable and eco-friendly features. 


\section{Biological control}

Application of fertilizers, pesticides, fungicides etc. are in increasing trend over the years to meet the food production requirements for ever-growing population. Such applications lead to environmental pollution and human and animal health hazards. Therefore, there is a need for alternate, eco-friendly measures in place of inorganic chemicals for control of pests/diseases (Kumar et al., 2012). In reference to present discussion on Phomopsis vexans, it would be apt to use plant based extracts, plant oils, bio-fungicides etc. or integrated disease management rather than chemical compounds. The biological agents or chemical compounds primarily inhibit the germination and growth of the conidia of Phomopsis vexans, resulting in proper seed germination, plant growth with lower PDI and higher fruit yield.

With regard to use of plant based products, Ram et al., (2012) have shown that plant extracts will have anti-microbial activity and such plant extracts found to inhibit the fungal growth in artificial media (Sneha et al., 2016). Lakshmi Nair (2011) reported an effective inhibition of mycelia growth of Phomopsis vexans with 30 per cent leaf extract of Ocimum and neem leaf. Jadeja (2003) reported that the plant extracts $(5 \%$ w/v) of Datura inhibited mycelia growth of Phomopsis vexans by 80.65 per cent, Eucalyptus (53.6\%), Ocimum $(53.3 \%)$ and neem (51.2\%). In vitro medium containing 20 to 30 per cent leaf extract (w/v) of Ocimum, Azadiracta, Lantana or Clerodendron inhibited the mycelia growth of Phomopsis vexans by 44.75 per cent (Lakshmi Nair, 2011). Similarly, other plant extracts, the garlic extract (5 and $10 \%, \mathrm{w} / \mathrm{v}$ ) inhibited the mycelia growth of $P$. vexans (Jakatimath et al., 2017). Seed treatment with botanicals, like garlic $(1: 1, \mathrm{w} / \mathrm{v})$ or Allamanda $(1: 1, w / v)$ extract decreased the incidence of seedling blight (Islam and Meah, 2011). The seed treatment with neem leaf extract $(100 \%$ $\mathrm{w} / \mathrm{v})$ for $30 \mathrm{~min}$ completely inhibited the Phomopsis vexans infection with a high seed germination percentage of 78.7 per cent (Kuri et al., 2011). Nimbidine, a neem based, ecofriendly and economical product proved effective, although slightly less effective than systemic fungicide like Indofil M-45 and thus it can be used in the management of the Phomopsis (Singh et al., 2012). Khanam (2015) reported that spraying Allamanda leaf extract $(1: 2, w / v)$ or neem leaf extract $(1: 2$, w/v) reduced the per cent disease incidence (PDI) over the control significantly. In a recent study, seed treatment for one hour with neem oil ( $5 \mathrm{ml} \mathrm{kg}^{-1}$ seed) resulted in 94.33 per cent seed germination which was at par to the seed treatment with carbendazim $(95.0 \%)$ and the neem oil was at par or better over the carbendazim $(0.2 \%)$ both in terms of seedling vigour and disease control (Priya Reddy, 2017). Although, many of the plant extracts are highly useful in controlling the Phomopsis vexans, these can be adapted depending on the availability of plant material in bulk.

The other approach could be identification of antagonistic microorganisms those suppresses the activity of pathogen but has growth promoting effect on the plant. For instance, an antagonistic fungus Trichoderma sp. the most studied and commercially available, works on the principle that, it competes with Phomopsis vexans (mycoparasitism) for nutrition / carbon source by secreting cell wall degrading enzymes. The Trichoderma synthesize cellulase and chitinase enzymes those breakdown the cellulose and chitin of fungus (Phomopsis vexans) and the derived carbon source will be utilised by the Trichoderma and thus inhibit the growth of the pathogen (Sharma and Singh, 2016). Trichoderma sp. found to inhibit the radial growth of Phomopsis vexans by 67.33 per cent and Aspergillus sp. by 38.5 per cent (Lakshmi 
Nair, 2011). Das et al., (2014) reported that per cent inhibition of mycelia growth was 84 per cent with Trichoderma viridae compared to 78.2 per cent with Trichoderma harzianum. Similarly, Ghosh (2017) also reported a lower fruit rot incidence (31.3\%) with Trichoderma viride as compared to the Trichoderma harzianum $(39.6 \%)$. The mechanism of action of Trichoderma viride could be secretion of cell wall degrading lytic enzyme and then kills the Phomopsis vexans (Ghosh et al., 2015). Further, the bio-control agents like Bacillus subtilis produce diffusible and volatile compounds, those lead to structural deformation of pathogen and subsequent death of pathogen (Chaurasia et al., 2005). Jakatimath et al., (2017) reported that fungal bio-agents ( $T$. harzianum) was better than bacterial bio-agents in inhibiting the growth of Phomopsis vexans.

Antagonistic Pseudomonas fluorescens and Trichoderma harzianum seed treatment and foliar sprays found effective against $P$. vexans (Srinivas et al., 2005). Seed treatment with bio-fungicide like Trichoderma species controls the Phomopsis vexans and hence decreases the incidence of seedling blight (Islam and Meah, 2011). Khanam (2015) have shown that spraying Trichoderma harzianum at fruiting stage was effective in controlling the fruit rot and at par to or superior to the chemical fungicide, bavistin-50WP, hence Trichoderma sp. can be effectively used to control Phomopsis vexans to yield on par to that of chemical (bavistin) treatment.

Ghosh (2017) reported that Trichoderma viride can serve as bio-pesticide comparable to that of blitax-50 and carbendazim in controlling the Phomopsis vexans in addition to stimulating the crop growth, hence it can be used as alternative to chemical fungicide. Therefore, it was suggested that seedling treatment with Trichoderma viride suspension $\left(10^{7}\right.$ spores $\left./ \mathrm{ml}\right)$ and consecutive foliar applications at 15 days interval after fruit initiation serve as effective control of fruit rot caused by Phomopsis vexans.

Trichoderma viride increased the seed germination, seedling vigour index and plant growth in terms of leaf area, number of leaves, dry weight and plant height (Ghosh, 2017, Priya Reddy, 2017). Ghosh (2017) reported that the Phomopsis vexans would cause 100 per cent fruit rot incidence, while addition of Trichoderma viride to Phomopsis vexans treated fruits showed only 20 PDI and Trichoderma viride was better than the Trichoderma harzianum. Trichoderma viride was on par to the blitax-50, hence Trichoderma viride can be used to treat and combat the Phomopsis vexans rot of brinjal with less than $36.3 \%$ PDI as against blitox-50 $(33.0 \%)$. Bio-control agents are natural and environmentally acceptable alternatives to chemical methods. Trichoderma sp. also serves as bio-pesticide and bio-fertilizer (Harman, 2006). Further, Trichoderma has good capacity to mobilize and uptake of soil nutrients (Chet et al., 1997), which could be competitively, inhibits the pathogen like Phomopsis vexans. Further, Rohini et al., (2016) reported beneficial effects of phylloplane colonizing bacteria (PCB) and rhizosphere colonizing bacteria (RCB) to control Phomopsis leaf blight of brinjal (Solanum melongena L.). Among 16 combinations of PCB and RCB tested, seed treatment with Pseudomonas fluorescens (an RCB) followed by foliar application of $B$. subtilis (a PCB) significantly increased root length $(6.3 \mathrm{~cm})$ and shoot length $(23.2 \mathrm{~cm})$, fresh weight $(2.51 \mathrm{~g})$ and dry weight $(0.373 \mathrm{~g})$ of seedling. This combination significantly reduced the disease incidence $(18.0 \%)$ and disease severity (0.54) in comparison with distilled water treated control $(91 \%$ and 6.0 , respectively). They suggested that combined application of bio-control agents is more efficient in improving plant growth and suppressing leaf blight disease caused by $P$. vexans in brinjal as compared to the control 
and carbendazim treatment. Further, Trichoderma secretes growth promoting hormones viz., zeatin, gibberellic acid, gluconic acid, citric acid and fumaric acid (Osiewacz et al., 2002) and have tendency to acidify soil and thus higher productivity (Gomez and Torre, 1994). Srivastava et al., (2015) have shown that the Trichoderma is more effective in acidic soils compared to the alkaline soil. These research findings suggest that the Trichoderma sp. and other bio-agents could be beneficial in replacing agrochemicals in brinjal cultivation and there is a need to identify isolates or species of such bio-agents for control of fungal infection to reach potential yields of brinjal without environmental hazards.

\section{Integrated method}

Although mechanical, chemicals or bio-agents can be effectively control the Phomopsis vexans effectively, the combined or integrated use of all the three methods would lead to higher fruit yields. For instance, healthy seed, treated with garlic or Allamanda extract and soil application of Trichoderma sp. effectively controlled the seedling blight caused by the $P$. vexans as compared to the bavistin (Islam and Meah, 2011).

Treating brinjal seed with garlic or Allamanda plant extract (1:1) along with soil application of Trichoderma (7-10 days of incubation) decreased the damping off $(27.25$ to $0 \%)$ and seedling blight (14.25 to $0 \%$ ) with increased seed germination of 89.75 per cent as against 64.5 per cent in control (Islam and Meah, 2011). Combination of fluorescent bacteria $(2 \%)+$ Ocimum leaf extract $(20 \%)+$ groundnut cake $(200 \mathrm{~g} / \mathrm{pot})$ resulted lesser disease incidence $(6.0 \%)$ and increased the fruit yield by 29.2 per cent over the Carbendazim $(0.1 \%)$ treatment (Lakshmi Nair, 2011). Bavistin 50WP (0.1 \%) in combination with micronutrients (Gypsum, $\mathrm{ZnO}$ and boric acid) found more effective in controlling fruit rot and resulted in higher fruit yield compared to the bavistin alone (Hossain et al., 2013).

Mulching with paddy straw in addition to the two sprays of carbendazim $(0.1 \%)$ at 15 day interval decreased the fruit rot incidence by 24.3 per cent compared to the carbendazim alone with consequent in increase in fruit yield by 34.5 per cent in mulching plus carbendazim (Ali et al., 2017).

Application of higher dose of nitrogen increased the disease incidence. However, application of potassium (30 to $60 \mathrm{~kg} \mathrm{ha}^{-1}$ ) decreased the fruit rot to $50.3 \%$, while application of phosphorus (64 $\mathrm{kg} \mathrm{ha}^{-1}$ ) decreased the disease incidence to 36.4 per cent (Sugha and Kumar, 2003). FYM treated with $T$. viride after soil solarisation, followed by seed treatment of carbendazim @ 0.2 per cent and four foliar sprays of carbendazim @ 0.1 per cent, gave maximum control of fruit rot incidence coupled with maximum yield (Sharma and Razdan, 2012). Therefore, under all possible conditions, it would be apt to practice the integrated in place of chemical fungicides, which are environmentally not safe.

It is concluded as follows

1. Seed treatment with plant extracts of neem leaf (20-30\%), neem oil @ 5 ml kg${ }^{1}$ seed effectively controls the Phomopsis vexans. However, seed treatment with Trichoderma viride (4g to $5 \mathrm{~g} \mathrm{~kg}^{-1}$ seed) would be more effective and easy to practice.

2. While crop cultivation, use of reduced level of nitrogen with higher rates of phosphorus and potassium fertilizer, in addition to use of Trichoderma viride or other species of Trichoderma (seed treatment; $5 \mathrm{~g} \mathrm{~kg}^{-1}$ seed) would decrease the fruit rot incidence and lead to higher fruit yields. 
3. Seedling treatment with $T$. viride spore suspension $\left(10^{7}\right.$ spore $\left./ \mathrm{ml}\right)$ and four consecutive sprays of this suspension at the interval of 15 days after initiation of fruits would control fruit rot infection and result in potential fruit yields.

\section{Acknowledgements}

Authors are thankful to Dr. R.C. Punia, Dr. S.S. Verma, Dr. V.S. Mor, Dr. Axay Bhuker and Dr. V.P.S. Sangwan, Department of Seed Science \& Technology, CCSHAU, Hisar for having rendered impetus learning in this area of research on Phomopsis vexans and to Dr. M.K. Prasanna Kumar and Dr. Y.A. Nanja Reddy, UAS, Bangalore for their suggestions in preparation of this review article

\section{References}

Agrawal, M.K., Fageria, M.S. and Dhaka, R.S. 2000. Breeding for multiple disease resistance in vegetables: A review. Agricultural Reviews. 21 (2): $125 \cdot 128$.

Akhtar, J. and Chaube, H.S. 2006. Variability in Phomopsis blight pathogen $(P$. vexans). Indian Phytopathology. 59 (4): 439-444.

Akhtar, J., Khalid, A. and Kumar, B. 2008. Effect of carbon sources, substrates, leachates and water grades on germinability of Phomopsis vexans. African Journal of Agricultural Research. 3: 549- 553.

Ali, M., Ashfaq, M., Akram, W., Sahi, S. T. and Ali, A. 2012. The physio- morphic characters of the brinjal (Solanum melongena L.) plant and their relationship with the jassid (Amrasca bigutulla) population fluctuation. Pakistan Journal of Agricultural Sciences. 49: 67-71.

Ali, A., Bhat, M., Ganaie, N., Ambardar, V.K. and Hassan, M.G. 2017. Prevalence and management through relative performance of organic mulches and fungi-toxicants of noxious Phomopsis fruit rot (Phomopsis vexans, Sacc. \& Syd.) Harter, in brinjal ecology of Kashmir. The Pharma Innovation Journal. 6(9): 318-323.

Anonymous. 2012. www.ikisan.com/tnbrinjal-history.html

Anonymous.

2013.www.worldatlas.com/articles/topeggplant-producing-countries-in-theworld. html

Anonymous.2015. Horticultural statistics at a glance.Pp. 151.

Anonymous. 2017. https://www.cabi.org/isc/datasheet/4048 8

Ashrafuzzaman, H. 2006. Udvid Rogbighan. Publication Bangla Academy, Dhaka1000, Bangladesh. Pp.260.

Avinash, V. S. and Hosmani, S. P. 2012. Effect of carbendazim on morphological and biochemical parameters of Sorghum bicolor. Paripex - Indian Journal of Research. 1(10): 12-14.

Beura, S.K., Mahanta, I.C. and Mahapatra, K.B. 2008. Economics and chemical control of Phomopsis twig blight and fruit rot of brinjal. Journal of Mycopathological Research. 46(1): 7376.

Bhardwaj, N.K., Singh, V., Tiwari, S.K. and Singh, M. 2014. Phenotyping of inbred lines for Phomopsis blight in brinjal. Vegetable Science. 41 (2): 195-197.

Bhatti, K.H., Kausar, N., Umer, R., Hussain, K., Nawaz, K and Siddiqi, E.H. 2013. Effects of biotic stresses on eggplant (Solanum melongena L.). World Applied Science Journal. 26 (3): 302311.

Bhushan, A. and Samnotra, R.K. 2017. Phenotypic stability studies for fruit yield and biotic stress traits in brinjal 
(Solanum melongena L.). Vegetos. 30 (Special-2): 349-358.

Campbell, R. 1989. Biological control of microbial plant pathogens. Cambridge University Press, Cambridge. Pp.432.

Chakrabarti, A.K. and Chowdhury, B. 1979. Effect of little leaf disease on brinjal plants of different ages. Vegetable Science. 6: 66-69

Chaudhury, B. and Kalda, T.S. 1968. Brinjal: a vegetable of the masses. Indian Horticulture. 12:21-22.

Chaukhe, A.N., Patil, M.J., Sawai, H.R., Parate, R.L. and Chargen, S.U. 2017. Fungicidal control of Phomopsis blight in brinjal. International Journal of Researches in Biosciences and Agriculture Technology. 2 (5): 385-387.

Chaurasia, B., Pandey, A., Palni, L.M.S., Trivedi, P., Kumar, B. and Colvin, N. 2005. Diffusible and volatile compounds produced by an antagonistic Bacillus subtilis strain cause structural deformations in pathogenic fungi in vitro. Microbiological Research. 160 (1): 75-81.

Chet, I., Inbar, J. and Hadar, Y. 1997. Fungal antagonists and mycoparasites. In: The mycota, environmental and microbial relationships, Wicklow, D.T. and B. Soderstrom (Eds. Vol. 4, SpringerVerlag, Berlin, Germany, Pp. 165-184.

Choudhary, B. and Gaur, K. 2009. The development and regulations of $B t$ brinjal in India. ISAAA Brief, 38.Pp. 12.

Cristina, M.B. 2002. Pesticide management of major pests and diseases of eggplant. Veggies Today, 2-3. htm.

Das, B. H. 1998. Studies on Phomopsis in the fruit of brinjal. M. S. Thesis, Department of Plant Pathology, Bangladesh Agricultural University, Mymensingh. Pp. 33-44.

Das, S.N. and Sharma, T.C. 2012. Some micro-fungi and their association on the incidence of diseases of brinjal (Solanum melongena L.) in western Assam. The Ecoscan. 1: 303 - 306 (Special Issue).

Das, S. N., Sarma, T.C. and Tapadar, S. A. 2014. In vitro evaluation of fungicides and two species of Trichoderma against Phomopsis vexans causing fruit rot of brinjal (Solanum melongena L.). International Journal of Scientific and Research Publications. 4 (9): 1-2.

Datar, V. V. and Ashtaputre, J. U. 1988. Studies on resistance to Phomopsis fruit rot in eggplant. Indian Phytopathology. 41: 214-219.

Ghosh, S.K., Pal, S., Banerjee, S., and Chakrabarty, N. 2015. In vitro study of lysis of cell wall preparation from Phomopsis vexans by lytic enzyme from some bio-control agents. International Journal of Current Microbiology and Applied Sciences. 4 (10): 153-157.

Ghosh, S.K. 2017. Study of some antagonistic soil fungi for protection of fruit rot (Phomopsis vexans) and growth promotion of brinjal. International Journal of Advanced Research. 5 (7): 485-494.

Gomez, A.G. and de la Torre, M. A. 1994. Mecanismos de corrosion microbianasobre los materialespétreos. Microbiología. 10: 111-112.

Harman, G.E. 2006. Overview of mechanisms and uses of Trichoderma sp. Phytopathology. 96: 190-194.

Hossain, M.I., Islam, M.R., Uddin, M.N., Arifuzzaman, S.M., and Hasan, G.N. 2013. Control of Phomopsis blight of eggplant through fertilizer and fungicide management. International Journal of Agricultural Research, Innovation and Technology. 3 (1): 66-72.

Howard, F.S. and David, H.G. 2007. Phomopsis fruit rot (Phomopsis Blight). High plains IPM Guide. University of 
Wyoming, University of Nebraska, Colorado State University.

Islam, S.J. and Sitansu, P. 1989. Chemical control of leaf blight and fruit rot of brinjal caused by Phomopsis vexans. Indian Journal of Mycological Research. 27 (2):159-163.

Islam, M.R. and Meah, M.B. 2011. Association of Phomopsis vexans with eggplant (Solanum melongena) seeds, seedlings and its management. The Agriculturists. 9 (1\&2): 8-17.

Islam, M. R., Meah, M. B., Islam, M. R., Islam, M. M. and Faruq, A. N. 2009. Studies on some physiological aspects of Phomopsis vexans causing Phomopsis blight and fruit rot of eggplant. J. Sher-e-Bangla Agric. Univ. 3 (1): 96-103.

Jadeja, K.B. 2003. Evaluation of different herbicides, fungicides, phytoextracts and bio-agents against Phomopsis vexans causing stem and branch blight in Brinjal. Journal of Mycology and Plant Pathology. 33 (3): 446-450.

Jain, M.R. and Bhatnagar, M.K. 1980. Efficacy of certain chemicals in the control of fruit rot of brinjal. Pesticides. 14: 27- 28.

Jakatimath, S., Mesta, R., Mushrif, S., Biradar, I.B and Ajjappanavar, P.S. 2017. In vitro evaluation of fungicides, botanicals and bio-agents against Phomopsis vexans, the causal agent of fruit rot of brinjal. Journal of Pure and Applied Microbiology. 11: 229-235.

Jayaramaiah, K.M., Mahadevakumar, S., Charithraj, A.P. and Janardhana, G.R. 2013. PCR based detection of $P$. vexans- The causative agent of leaf blight and fruit rot disease of brinjal (Solanum melongena L.). International Journal of Life Sciences. 7(1): 17-20.

Kalda, T.S., Swarup, V. and Choudhury, B. 1976. Studies on resistance to Phomopsis blight in eggplant (Solanum melongena L.). Vegetable Science. 3: 6570.

Kalda, T.S., Swarup, V. and Choudhury, B. 1977. Resistance to Phomopsis blight in eggplant. Vegetable Science. 4: 90-101.

Kannan, R., Ananthan, M. and Balasubramani, P. 1998. Anthracnose a menace in chilli cultivation. Spice India. 11: 2-3.

Karmakar, P. and Singh, Y.V. 2017. Screening of interspecific hybrids and their parents for resistance to Phomopsis blight in brinjal. Vegetable Science. 44 (1): 38-41.

Kaur, S., Kaur R., Kaur, P. and Singh, D. 1985. Studies on wilt and fruit rot of brinjal caused by Fusarium semitectum. Indian Phytopathology. 38: 736- 738.

Kaushal, N. and Sugha, S.K. 1995. Role of Phomopsis vexans in damping off of seedlings in eggplant and its control. Indian Journal of Mycology and Plant Pathology. 25:189-191.

Kevin, C. 2006. Pepper and eggplant disease guide (Ed. Kevin et al., 2006), Seminis, sem-

12095_pepperdiseases_8p5x11_072313 .pdf. Pp. 44.

Khalil, M.I., Meah, M.B. and Islam, M.M. 2013. Morphological and molecular characterization of eggplant lines for resistant to Phomopsis blight and fruit rot. International Journal of Agricultural Research, Innovation and Technology. 3 (1): 35-46.

Khan, N. U. 1999. Studies on epidemiology, seed borne nature and management of Phomopsis fruit rot of brinjal. M.Sc. Thesis, Department of Plant Pathology, Bangladesh Agricultural University, Mymensingh, Bangladesh, Pp. 42-62.

Khanam, S. 2015. Evaluation of selected ecofriendly components against Phomopsis fruit rot (Phomopsis vexans) of eggplant. M.Sc. Thesis, Department of 
Plant Pathology, Sher-e-Bangla Agricultural University.

Kidasha, F.M. 2010. Effect of Phomopsis blight on eggplant production in Nyagatare district. M.Sc. Thesis, Faculty of Agriculture, Umutara Polytechnic.

Kumar, R., Maurya, S., Kumari, A., Choudhary, J., Das, B., Naik, S.K. and Kumar, S. 2012. Bio-control potentials of Trichoderma harzianum against Sclerotia fungi. The Bioscan. 7 (3): 521 525.

Kuri, S. K., Islam, R.M. and U. Mondal. 2011. Antifungal potentiality of some botanical extracts against important seed borne fungal pathogen associated with brinjal seeds, Solanum melongena L. Journal of Agricultural Technology. 7(4):1139-1153.

Lakshmi Nair. 2011. Management of Phomopsis blight and fruit rot of brinjal (Solanum melongena L.), M.Sc. (Agri.) Thesis, Department of Plant Pathology, Kerala Agri. Univ.

Mahadevakumar, S. and Janardhana, G.R. 2015. Disease incidence, severity and molecular characterization of Phomopsis vexans causing leaf blight and fruit rot of brinjal in Karnataka (India): National Symposium On Understanding host-pathogen interaction through science of Omics, March 16-17, 2015, ICAR-Indian Institute of Spices Research, Marikunnu P.O., Kozhikode -673012, Kerala, Pp.44.

Mahadevakumar, S. and Janardhana, G.R. 2016. Leaf blight and fruit rot disease of brinjal caused by Diaporthe vexans (Phomopsis vexans) in six agroecological regions of South West India. Plant Pathology and Quarantine. 6(1): 5-12.

Mahadevakumar, S., Amruthavalli, C., Sridhar, K.R. and Janardhana, G.R. 2017. Prevalence, incidence and molecular characterization of Phomopsis vexans causing leaf blight and fruit rot disease of brinjal in Karnataka (India). Plant Pathology and Quarantine. 7(1): 41-58.

Meah, M.B., Hossain, M.D. and Islam, M.R. 2002. Development of an integrated approach for management of Phomopsis blight and fruit rot of eggplant in Bangladesh. Annual research report (2001-2002). Department of Plant Pathology, Bangladesh Agricultural University, Mymensingh, Bangladesh. pp. 8-10.

Mohanty, A.K., Panda, R.N., Sethi, P.N. and Kar, A.K. 1994. Efficacy of certain fungicides in controlling Phomopsis vexans causing fruit rot of brinjal. Orissa Journal of Agricultural Research. 7(suppl.): 85-86.

NHB. 2017. $3^{\text {rd }}$ advance estimates of area and production of horticultural crops (201617), Areapro. 16-17: 3.

Osiewacz, H. D. 2002. Molecular biology of fungal development Marcel Dekker, New York.

Pan, S. and Acharya, S. 1995. Studies on the seed borne nature of Phomopsis vexans (Sacc. and Syd.) Harter. Indian Agriculturist. 39(3): 193-198.

Pandey, A. 2010. Studies on fungal diseases of eggplant in relation to statistical analysis and making of disease calendar. Recent Research in Science and Technology, 2(9): 1-3.

Pandey, D. T. 2010a. Phomopsis blight in brinjal: Symptoms, cause and control, Agropedia.

Pandey, K.K., Pandey, P.K., Kalloo, G. and Chaurasia, S.N.S. 2002. Phomopsis blight in brinjal and sources of resistance. Indian Phytopathology. 55 (4): 507-509.

Panwar, N. S., Chand, J. N., Singh, H. and Paracer, C. S. 1970. Phomopsis fruit rot of brinjal (Soloanum melongena L.) in 
the Punjab. I. Viability of the fungus and role of seeds in disease management. Journal of Research PAU. Ludhiana. 7: 641.

Phansawan, B., Prapamontol, T., Thavornyutikarn, P., Chantara, S., Mangklabruks, A. and Santasup, C. 2015. A sensitive method for determination of carbendazim residue in vegetable samples using HPLC-UV and its application in health risk assessment. Chiang Mai Journal of Sciences. 42(3): 681-690.

Priya Reddy, Y.N. 2017. Studies on the effect of plant oils and bio-fungicides on seed borne pathogens of chilli and brinjal seeds. M.Sc. (Agri.) thesis, Department of Seed Science and Technology, CCSHAU, Hisar

Priya Reddy, Y.N., Jakhar, S.S. and Dahiya, O.S. 2017. Eco-friendly measures for control of Phomopsis vexans of brinjal. National conference on harmony with nature, 21-23 ${ }^{\text {rd }}$ December 2017, Warangal, Telangana, Souvenir and Abstracts. Pp. 70-71.

Rajavel, R. 2000. Seed borne Colletotrichum capsici and its management. M.Sc. Thesis. Tamil Nadu Agricultural University, Coimbatore, India

Ram, G. D., Verma, D. K. and Yadav, I. 2012. Evaluation of the antimicrobial activity of crude herbal extracts against different microorganisms. The Bioscan. 7(2): 263- 266.

Rangaswamy, G. and Mahadevan, A. 2002. Diseases of crop plants in India. $4^{\text {th }} \mathrm{Edn}$. Pp. 286-334. Prentice Hall of India Private Ltd. New Delhi.

Rathnamma. 2014. Studies on little leaf of brinjal caused by Candidatus phytoplasmatrifolii, M.Sc. (Ag.) Thesis, Department of Plant Pathology, UAS, Dharwad, Karnataka.

Rohini, Gowtham, H. G. and Niranjana, S. R., 2015. Evaluation of efficacy of fungicides against Phomopsis leaf blight of brinjal (Solanum melongena L.). International Journal of Agricultural Science and Research.. 5 (6): 45-50.

Rohini, Gowtham, H.G., Hariprasad, P., Brijeshsingh, S. and Niranjana, S.R. 2016. Biological control of Phomopsis leaf blight of brinjal (Solanum melongena L.) with combining phylloplane and rhizosphere colonizing beneficial bacteria. Biological Control. 101: 123-129.

Ronald, F. 2009. Phomopsis fruit rot and blight on eggplant. Texas Agri Life Extension Service; The Texas A\&M System, PLPA-Eg009-01.

Sekara, A., Cebula, S. and Kunicki, E. 2007. Cultivated eggplants- origin, breeding objectives and genetic resources, a review. Folia Horticulturae. 19(1): 97-114.

Sharma, M. and Razdan, V. K. 2012. Integrated disease management of Phomopsis leaf blight and fruit rot of brinjal (Solanum melongena L.). Journal of Mycopathological Research. 50 (2): 167-175.

Sharma, K.K. and Singh, U.S. 2016. Qualitative enzyme assay and sclerotia parasitization by fungal antagonist Trichoderma. The Bioscan. 11(4): 28672872 (Supplement on Plant Pathology).

Singh, R.S. 1987. Plant pathogens. Second Edition. New Delhi, India: Oxford and IBH Publishing Company.

Singh, R.S. 1992. Disease of vegetable crops. Second Edition, Oxford and IBH Publishing Company Pvt. Ltd.New Delhi, Bombay and Calcutta. Pp. 119211.

Singh, D. and Chakrabarti, A.K. 1982. Chemical control of Phomopsis fruit rot of brinjal. Indian Phytopathology. 35: 314-315.

Singh, B.R. and Singh, D.R. 1975. Brinjal mosaic incidence and effect on yield. 
Indian Journal of Farm Sciences. 3: 118-119.

Singh, R., Singh, P.C., Kumar, D. and Sachan, N.S. 2012. Management of Phomopsis leaf blight of brinjal through different fungicides and biopesticide. HortFlora Research Spectrum. 1: 371374.

Singh, B.K., Singh, S., Singh, B.K. and Yadav, S.M. 2014. Some important plant pathogenic disease of brinjal and their management. Plant Pathology Journal. 13 (3): 208-213.

Sneha, S., Maurya, S. and Choudhary, A.K. 2016. Antifungal efficacy of aqueous extracts of some spices against Sclerotium rolfsii L. The Bioscan. 11 (3): 1537-1540.

Srinivas, C., Niranjana, S. R. and Shetty, H. S. 2005. Effect of bioagents and fungicides against Phomoposis vexans and on seed quality of brinjal. Crop Improvement. 32(1): 95-101.

Srivastava, M., Pandey, S., Mohammad, S., Singh, V.K., Trivedi, A. S., Maurya, M. K. and Srivastava, Y. K. 2015. Biocontrol mechanisms evolved by Trichoderma sp. against phytopathogens: a review. The Bioscan. 10(4): 1713-1719.

Sugha, S.K. and Kumar, S. 2003. Effect of fertilizers on Phomopsis blight disease (Phomopsis vexans) of brinjal (Solanum melongena). Indian Journal of Agricultural Sciences. 73: 32-34.

Thippeswamy, B., Krishnappa, M., Chakravarthy, C. N. 2005. Location and transmission of Phomopsis vexans and Alternaria solani in Brinjal, Indian Phytopathology. 58(4): 410-413.

Thippeswamy, B., Krishnappa, M., Chakravarthy, C.N., Sathisha, A.M., Jyothi, S.U. and Kumar, K.V. 2006. Pathogenicity and management of Phomopsis blight and leaf spot in brinjal caused by Phomopsis vexans and Alternaria solani. Indian Phytopathology. 59(4): 475-481.

Udayanga, D., Liu, X., McKenzie, E.H.C., Chukeatirote, E., Bahkali, A.H.A. and Hyde, K.D. 2011. The genus Phomopsis: biology, applications, species concepts, and names of common phytopathogens. Fungal Diversity. 50: 189-225.

Vinodkumar. 2012. Brinjal diseases and their control, www.agropedia.iitk.ac.in/content/brinjal -diseases-and-their-control

Vishunavat, K. and Kumar, S. 1993. Detection and transmission of seedborne inoculums of Phomopsis vexans (Sacc. and Syd.) Harter. and the effect of infection on seed quality in egg plant (Solanum melongena L.). Seed Research. 21: 66-71.

\section{How to cite this article:}

Priya Reddy, Y.N., S.S. Jakhar and Dahiya, O.S. 2018. Management of Fruit Rot of Brinjal Caused by Phomopsis vexans. Int.J.Curr.Microbiol.App.Sci. 7(06): 2826-2839. doi: https://doi.org/10.20546/ijcmas.2018.706.332 